The History of Capitalism in Mexico: Its Origins, 1521-1763 
1LS Translations from Latin America Series

Institute of Latin American Studies

University of Texas at Austin 


\section{The History of}

Capitalism in Mexico:

Its Origins, 1521-1763

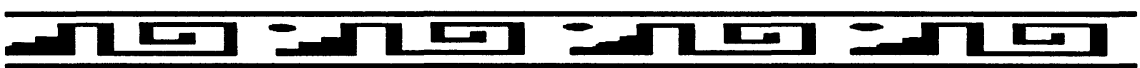

By Enrique Semo

Translated by Lidia Lozano

$\checkmark \boldsymbol{~ U n i v e r s i t y ~ o f ~ T e x a s ~ P r e s s , ~ A u s t i n ~}$ 
Copyright $\odot 1993$ by the University of Texas Press

All rights reserved

Printed in the United States of America

First Edition, 1993

Requests for permission to reproduce material from this work should be sent to

Permissions, University of Texas Press, P.O. Box 7819, Austin, Texas 787137819

\section{Library of Congress Cataloging-in-Publication Data}

Semo, Enrique.

[Historia del capitalismo en México. English]

The history of capitalism in Mexico : its origins, 1521-1763 / by Enrique

Semo ; translated by Lidia Lozano.

p. cm. - (Translations from Latin America series)

Includes bibliographical references and index.

ISBN 0-292-73069-1. — ISBN 0-292-77669-1 (pbk.)

1. Mexico-Economic conditions-1540-1810. 2. Mexico-Social conditions-To 1810. 3. Capitalism-Mexico-History. 4. Working classMexico-History. I. Title. II. Series.

HC135.S36513 1993

$330.12 ' 2 ' 0972-\mathrm{dc} 20$

ISBN 978-0-292-76610-5 (library e-book)

ISBN 978-0-292-76611-2 (individual e-book) 
To Esther and Jacques, the immigrants 
THIS PAGE INTENTIONALLY LEFT BLANK 